\title{
Die priesterskap van die gelowiges en die ampte in die kerk
}

\author{
AD Pont
}

\section{INLEIDING}

Die leer van die priesterskap van alle gelowiges word alleen in die Calvinistiese kerke as ' $n$ min of meer uitgewerkte leerstuk gevind. Dit kom as sodanig voor in die Tweede Switsere Geloofsbelydenis 1560. Interessant genoeg, het Calvyn self dit nie besonder belangrik geag nie (W Niesel, 1957, S 202). Gewoonlik word oor die priesterskap van die gelowiges gehandel in samehang met die leer van die ampte in en van die kerk. Juis vanweë daardie samehang ontstaan die vraag wát die presiese samehang is. Daarby kom dat waar die hervormde vadere normaalweg van die priesterskap van die gelowiges gepraat het, dit in die 19de eeu, in navolging van Kuyper, gewoonte geword het om van die amp van die gelowiges te praat. Juis dié benaming veroorsaak dat die samehang met die ampte nogal belangrik word.

\section{ENKELE HISTORIESE OPMERKINGS}

Vir die doeleindes van hierdie uiteensetting is dit seker nie nodig om volledig op die geskiedenis-agtergrond van die priesterskap van die gelowiges in te gaan nie. (AD Pont, 1964, bl 1-10). Tog is die volgende momente wel van belang.

Dit is opvallend in die Nuwe Testament dat die priester-amp en priester-taak nêrens genoem word as 'n amp of 'n dienswerk wat in die Nuwe-Testamentiese kerk verrig moet word nie (vgl 1 Korintiërs 12:28-30 en Efesiërs 4:11-12). In die Nuwe Testament is daar slegs sprake van die priesterskap van Christus (Hebreërs 6:20 en 7:26-27), en daarnaas van die priesterskap van die gelowiges (1 Petrus 2:9 en Openbaring 5:10). Die priesterskap van die gelowiges is ten nouste verbind met die priesterskap van Jesus Christus en die offer wat $\mathrm{Hy}$ gebring het (Openbaring 5:9-10, 1 Petrus 2:5, Romeine 12:1, Hebreërs 7:27, 9:14 en 13:15). Die Nuwe-Testamentiese beeld wat na vore kom, is dat ons Here Jesus Christus deur sy lewe, werk, offer en opstanding 'n nuwe gemeenskap skep. Hy is die hoëpriester van 'n 
nuwe algemene priesterskap wat in die nuwe verbond saamgevat is en wat 'n groot dienswerk in die wêreld moet verrig. Deur die doop word die gelowige tot priester gewy (Hebreërs 10:22, Titus 3:4-7, Johannes 3:5 en Efesiërs 5:26-27) en is die taak van die algemene priesterdom om offers te bring (Romeine 12:1). Die algemene priesterdom is ' $n$ wisselbegrip vir die kerk as aanduiding van die volk van God wat deur die nuwe verbond (of hernude verbond) in ' $n$ besondere verband met God staan. Die aard, die dienswerk van die kerk in die wêreld en die apostolêre opdrag van die kerk (= die algemene priesterdom) staan in noue verband met die dienswerk van Christus.

Die offerande wat die gelowige as priester bring, is die gebed, die diens-aan-God insluitende die godsdiensoefening en die apostolaat in èn aan die wêreld. So gesien, is die leer van die algemene priesterskap 'n onderdeel van die leer van die kerk, veral ten opsigte van die ampsleer, en dan ook in samehang met die eenheid van die kerk wat geleë is in die eenheid in die ware geloof. Die algemene priesterskap van die gelowige wat so nou verbind is met die hoëpriesterskap van Christus is 'n uitdrukking van die noue verbintenis van Christus met die gelowiges wat op hulle beurt weer saamgevat is in die verbond. Dit is ' $n$ sekere parallel van die Pauliniese beeld waar die gelowiges gesien word as 'n liggaam waarvan Jesus Christus die enige Hoof is.

Die opvatting dat àlle gelowiges priesters is, dat die volk van God 'n algemene priesterdom is, het in die vroeë kerk betreklik gou vervaag. In die plek van die algemene priesterskap word die amp van priester dan heringestel. Dit gebeur, soos die nagmaal verstaan word, as 'n herhaling van die éénmalige offer van Christus. Dit hang ook saam met die feit dat die histories-empiriese kerk benadruk word ten koste van die geestelike begrip van die kerk. Dàn kom die hiërargies-ingerigte geestelike amp na vore wat skerp onderskei word van die gelowiges wat dan as leke aangedui word. Die verskuiwings kom veral vanaf die tweede eeu na vore en by Cyprianus, oorl 258, is daar in sy leer van die kerk geen ruimte meer vir die algemene priesterskap van die gelowiges nie.

Dié ontwikkeling het in die Roomse Kerk voortgegaan en mond uit in die dogma dat Maria na die hemel opgevaar het. Maria is daar die simbool van die ongetroude priesterstand en haar opname in die hemel beteken 'n vergoddeliking van die Roomse, heilsbemiddelende priesterdom. Dit staan natuurlik in direkte kontras met die leer 
van die algemene priesterskap van die gelowiges (AD Pont, 1964, bl 3. Vgl ook I Klug, 1939, bl 506-507). In die Middeleeue kom die leer van die algemene priesterskap van die gelowiges sporadies voor waar teoloë hulle verset téén die veruitwendigde, hiërargies-bepaalde en heil-bemiddelende kerk.

Hier kan gedink word aan Hugo van St Victor 1096-1141, John Wycliffe 1329-1384, Johannes Huss 1369-1415 en ook Wessel Gansfort 1420-1589.

In die tyd van die kerkhervorming is dit veral Martin Luther wat die leer van die algemene priesterskap weer sterk op die voorgrond plaas veral in sy geskrif van 1520 An den christlichen Adel. Hy benadruk, op grond van 1 Petrus 2:9, die algemene priesterskap van alle gedooptes en met die oog op 1 Korintiërs 14:30 en Johannes 6:45 stel hy dat elke gelowige in staat is om die Heilige Skrif te lees, te verstaan èn uit te lê. Dit is nie die prerogatief van enkelinge nie, maar van alle gelowiges.

Baie kortliks kan mens Luther se standpunt miskien as volg saamvat: In die Nuwe Testament word die begrip priester slegs ten opsigte van Christus en verder van alle gelowiges gebruik. Christus is priester omdat $\mathrm{Hy}$ voor God vir ons intree en vir ons bid, Homself vir ons offer en ons deur sy Gees leer en lei. Omdat elke gelowige deur die geloof met Christus verenig is, kan elke gelowige sonder bemiddeling sèlf voor God staan, vir ander mense bid, homself as geestelike offer aan God wy en as één wat deur Christus met sy Gees gesalf is, ander ook leer en lei. Dit beteken dat in die volk van God (= die kerk) alle Christen-gelowiges op dieselfde manier priester is omdat alles wat Christus vir sy gelowiges is, beteken en gegee het, aan almal gelykelik gegee is. Ook die gesag van die Woord en die sakrament behóórt aan die priestervolk (= die kerk). Hierdie gemeenskaplike kan enkelinge egter alleen nă 'n besondere opdrag as ampsdraer in die gemeente uitoefen. Wat die besondere amp betref, beteken dit dat die amp nié 'n besondere eiesoortige priesterskap (= sacerdotium) is nie, dit het géén hoëre priesterlike waardigheid nie en dit is ook nie deel van ' $n$ hoëre geestelike of priesterlike stand nie. Aangesien Christus-die-priester Homself geoffer het, het die Christelike ampsdraer géén ander offer-bevoegdheid as om homself te offer vir die ănder nie. (Vgl W Stein, 1974, S 204).

Alle Christene is priesters, so stel Luther dit. Dít beteken steeds dat alle gelowiges ' $n$ geestelike volk is wat voor die aangesig van God leef, hulle is sy verloste kinders deur die geloof in Christus ( $H$ 
Lieberg, 1962, S 40-68). In die breë gesien is hierdie her-formulering van die priesterskap van die gelowiges gemeenskaplik by al die hervormers, want dit is die basis van hulle verwerping van die Roomse hiërargies-geordende priesterdom. Dit is egter opvallend dat dié her-waardering van die priesterskap van die gelowiges by die hervormers nié lei tot 'n verwerping van die gemeentelik-kerklike amp nie. Die teendeel is eerder waar.

Hoewel Martin Bucer, die hervormer van Straatsburg en in sekere sin die kerklike leermeester van Calvyn, die priesterskap van die gelowiges anders begrond as Luther, stel hy nadruklik dat die priesterskap van alle gelowiges meebring dat elkeen die taak het om sy medegelowige se geloof in Christus te vernuwe sodat almal se lewe in Christus sal groei en toeneem. Dit moet hulle doen deur mekaar te onderrig, te waarsku, aan te spoor, te berispe, te troos en te rig (W van 't Spijker, 1970, bl 342). Bucer beklemtoon voortdurend, téén Rome enersyds en teen die spiritualiste en sektariërs andersyds, dat die priesterskap van die gelowiges, "de dienst van de broederschap" nie deur die amp opgehef of belemmer word nie (W van 't Spijker, 1970, bl 343).

Hoewel Calvyn, soos gestel, die priesterskap van die gelowiges nie benadruk nie, maak hy ook melding daarvan om daarmee die kwaliteit van die volk van God, die kerk, die geroepe gelowiges te omskrywe. Niesel wys daarop dat Calvyn in sy omskrywing van die kerk baie méér gebruik maak van die Pauliniese beeld van die liggaam van Christus en dat daarom die begrip, priesterskap van die gelowiges, by hom nie op die voorgrond staan nie (W Niesel, 1957, S 202).

As Calvyn oor die priesterskap van die gelowiges praat, dan handel hy daaroor wanneer hy praat oor die drie ampte van Christus (Joh Calvinus, 1559, Tom II XV), naamlik dié van profeet, koning en priester. Dáár stel Calvyn nadruklik dat daar net één priester is, Christus die Hoëpriester. Maar dan stel hy (Joh Calvinus, 1559, II XV 6):

"Verder dra Christus die amp van priester nie alléén sodat hy deur die ewige wet van die versoening die Vader gunstig en genadig teenoor ons sou stem nie, maar ook om ons in so 'n groot en eerbare gemeenskap op te neem (Openb 1:6). Want ons, wat in onsself bederf is, maar in Hom priesters is, offer onsself en al wat aan ons behoort, aan God en tree nou vryelik die hemelse heiligdom in sodat die offerandes van gebed en 
lofprysing wat van ons kom, aangenaam en van goeie reuk voor die aangesig van God is."

Calvyn se denke is duidelik. Christus is die enigste profeet, priester en koning, maar $\mathrm{Hy}$ is dit nié vir Homself alléén nie, maar óók vir sy liggaam, die kerk (Joh Calvinus, 1559, II XV 2). Die kerk, dit wil sê, die gelowiges, is so gesien 'n korporatiewe priesterdom. Nêrens, sê Calvyn, word van die enkeling-gelowige gepraat as ' $n$ priester of as ' $n$ koning of as ' $n$ heilige nie. Die begrippe, as hulle in die enkelvoud voorkom, verwys slegs na Christus. Maar in Christus, in sy naam, kan daar wèl gepraat word van priesters, heiliges en 'n koninkryk wat die kerk is. Die kerk, die volk van God, besit 'n korporatiewe priesterskap omdat die kerk as liggaam, Christus as Hoof het.

As Calvyn hieroor handel, beskryf hy by voorkeur Christus as die Middelaar, want as Middelaar tree Christus vir ons in by God en maak Hy van ons, wat mensekinders is, kinders van God. Immers Christus het Hom met òns vereenselwig sodat ons, deur die genade, deel kan kry aan Hom en sy werk. So stel hy (Joh Calvinus, 1559, II VII 1):

“Want dit het Moses aan hulle voorgestel as die doel van hulle aanneming tot kinders dat hulle vir God tot 'n koninkryk van priesters en ' $n$ heilige nasie (Eks 19:6) sal wees .... Daarom word hierdie woord van Moses heeltemal korrek deur Petrus omgestel wanneer hy leer dat die volheid van die genade, waarvan die Jode onder die wet 'n voorsmaak gekry het, in Christus aan die lig gebring is. 'Julle daarenteen, is die uitverkore volk, 'n koninklike priesterdom' (1 Pet 2:9). Want hierdie omstelling van die woorde het hierdie bedoeling, dat hulle aan wie Christus deur die evangelie verskyn het, meer ontvang het as hulle vadere, omdat hulle almal met 'n priesterlike en koninklike eer toegerus is sodat hulle, omdat hulle op hulle Middelaar vertrou, vryelik voor God se aangesig kan kom."

Calvyn beklemtoon dat die gelowige deur God aangeneem word en dan in 'n gelowige gemeenskap geplaas word. Calvyn sien die gelowige nooit as 'n alleenstaande enkeling nie, maar altyd as deel van 'n gelowige gemeenskap, die kerk. Die gelowige word aangeneem tot kind van God en só word hy priester met 'n dienstaak ten opsigte van sy medegelowige in die gemeenskap van gelowiges. By Calvyn is die priesterskap van die gelowiges altyd 'n korporatiewe 
priesterskap wat bestaan omdat die gelowiges in die gemeenskap met Christus deel kry aan sy priesterskap.

Hierdie priesterskap is 'n geestelike voorreg, 'n persoonlike roeping, wat enersyds die gelowige toegang tot God gee, andersyds 'n verantwoordelikheid ten opsigte van die gemeenskap van gelowiges, die kerk, en ten derde bring dit mee dat die gelowige sy leefwêreld moet verstaan as die plek waar sy priesterskap beoefen moet word (AD Pont, 1964, bl 7).

Ten slotte is dit miskien tog belangrik om 'n oomblik te let op die formulering van die Tweede Switserse Geloofsbelydenis 1560. Dit is die enigste van die calvinistiese belydenisskrifte wat die priesterskap van die gelowiges omskryf. Daar word dan gestel (Confessio Helvetica posterior, 1560, XVIII, 10).

"Die apostels van Christus noem almal wat in Christus glo
priesters, dit dan nie met betrekking tot hulle dienswerk (minis-
terium) nie, maar omdat al die gelowiges, wat konings en
priesters gemaak is, deur Christus hulle geestelike offerandes
aan God mag bring (Eks 19:6, 1 Pet $2: 9$, Openb 1:6). Die amp
(ministerium) dan en die priesterskap is twee sake wat groot-
liks van mekaar verskil. Want die priesterskap, soos ons nou
net gestel het, kom alle Christene toe, maar nie die amp nie. En
ons het die amp nie uit die kerk weggeneem toe ons die pous-
like priesterdom uit die kerk gestoot het nie..."

Dan beklemtoon die belydenisskrif dat Christus vir ewig die enigste priester is en bly en dat dáárom die ampsdraers ook nie priesters word nie sodat niks van die priesterskap van Christus weggeneem sal word nie.

\section{DIE AMP OF MINISTERIUM IN DIE KERK}

Dit bring ons dan vanself by die saak van die amp of dienswerk in die kerk èn die vraag hoe dít met die priesterskap van die gelowiges korreleer. Dan moet ten eerste gestel word dat die gedagte van die priesterskap van die gelowiges, hoewel dit net by implikasie in ons belydenisskrifte gestel word, implisiet is ten opsigte van die hele ekklesiologie (AD Pont, 1964, bl 8).

Soos die hervormde vadere die saak van die priesterskap van die gelowiges uit die Skrif afgelees het, net so het hulle ook tot die gevolgtrekking gekom dat die amp of dienswerk-in-opdrag van 
Christus deel is van die opdrag van Christus aan sy kerk. Dit was veral Calvyn wat aan die amp sy duidelike omskrywing en plek in die kerk gegee het. So stel hy (Joh Calvinus, 1559, IV 3.2):

"Christus, sê hy (dit is: Paulus) het opgevaar bo alle hemelruimtes uit om alles met sy teenwoordigheid te vul (Ef 4:10). Dit is die manier waarmee Hy alles met sy teenwoordigheid vul dat $\mathrm{Hy}$, deur middel van die dienaars, aan wie $\mathrm{Hy}$ hierdie dienswerk opgedra het en die genade gegee het om die dienswerk te doen, sy gawes aan die kerk uitdeel en verdeel, en Homself so, in 'n sekere sin, teenwoordig bewys, terwyl Hy die krag van sy Gees openbaar in hierdie instelling van Hom sodat dit nié verniet of nutteloos sal wees nie. So word die heiliges weer opgerig, so word die liggaam van Christus opgebou, so neem ons, deur alles in Hom toe, wat die Hoof is. So groei ons onderling saam en so word ons almal gebring tot die eenheid van Christus as die profesie onder ons $\mathrm{krag}$ het, as ons die apostels ontvang, as ons die leer, wat aan ons verkondig word, nié verag nie. Almal dus wat hierdie ordening, wat ons hier behandel, en hierdie soort regering probeer vernietig of verkleineer, asof dit minder noodsaaklik sou wees, beplan eintlik die verstrooiing, of beter gesê, die val en die ondergang van die kerk."

Veral uit die laaste paar woorde blyk dit dat Calvyn die dienswerk van die amp as noodsaaklik vir die ware kerk beskou. (Vgl ook Joh Calvinus, Comm Ephes IV 2). Juis omdat in die beginjare daar weinig orde was rondom die amp en die verskillende hervormde vadere, op hierdie vlak, dikwels aarselende uitsprake gemaak het, het Calvyn besondere aandag aan die saak van die amp gegee. Calvyn, méér as enigeen van die ander hervormers, het die vaste orde en reël vir die dienswerk van die amp in die kerk geskep. Dit is werklik opvallend hoe die essensie van die amp, soos Calvyn dit uiteengesit het, oral waar calvinistiese kerke ontstaan het, dieselfde gebly het.

Dit is dus duidelik dat daar ' $n$ amp in die kerk moet wees. As ons nou vra na die verhouding amp: volk van God of dienskneg: gemeente-kerk, dan kan die volgende na vore gebring word.

\subsection{Roeping}

Hoewel àlle gelowiges geroepe priesters was, is hulle nié almal 
ampsdraers nie. Slegs dié gelowiges wat in die besonder tot die amp geroep is, kan dié dienswerk ontvang. Dié standpunt word veral deur Zwingli skerp gestel as hy sê (CR, 4, bl 425).

"Geen ware Christen het ooit een van hierdie ampte vir homself toegeëien nie behalwe wanneer hy deur God gestuur is of gekies is deur die kerk of die apostels wat ook niks anders as 'n roeping en opdrag is nie."

Calvyn huldig presies dieselfde standpunt en stel dit nie alleen in die Institutio nie, maar ook in die Geneefse Kerkorde, art 5 (AD Pont, 1981, bl 23).

"Sodat daar geen wanorde in die kerk sal wees nie, mag niemand sonder ' $n$ beroep hom in hierdie diens indring nie."

Ook die Nederlandse Geloofsbelydenis, art 31 is baie uitgesproke:

"Daarom moet elkeen terdeë daarteen waak om met onbehoorlike middele hom in te dring; hy is verplig om te wag totdat hy deur God geroep word, sodat hy van sy roeping oortuig kan wees en sekerheid kan hê dat dit van God kom."

Die roeping tot die dienswerk van die amp is nie 'n roeping tot priesterskap nie, maar 'n roeping tot die opbou van die kerk deur die duidelik-omskrewe dienswerk. Die roeping tot die amp volg dus op die roeping tot die geloof. Die kerklike amp is veranker in die communio sanctorum, die ware gelowiges, maar tog weer duidelik daarvan onderskei.

Wat die roeping betref, onderskei Calvyn in die inwendige en uitwendige roeping en dan is die inwendige roeping 'n saak tussen God en die gelowige (Joh Calvinus, 1559, IV 3.10-11) en daarop volg die uitwendige roeping deur middel van die gemeente vir ' $n$ spesifieke dienswerk in die gemeente. Daarop volg dan die bevestiging. Die roeping sowel in- en uitwendig is altyd 'n roeping van God. Dit veral omdat die Hoofskap van Christus oor sy liggaam, dit is die kerk, voortdurend die uitgangspunt van alle kerkordenende denke is (vgl AD Pont, 1981, bl 192 v). Dit bring mee dat die amp konsekwent as ' $n$ dienswerk omskryf word, want die ampsdraer is primêr dienskneg-van-Christus. 


\subsection{Die amp as opdrag van Christus}

Waar Luther baie klem lê op die feit dat Christus die amp ingestel of beveel het, wil Calvyn dit liewer sien as 'n opdrag of ordening van Christus om sodoende die sakramentele karakter wat Rome aan die amp verbind, te vermy. Dit is opvallend dat Calvyn en die calvinistiese belydenisskrifte selde indien ooit die woord amp gebruik, maar altyd benadruk dat dit ' $n$ diens of ' $n$ dienswerk (ministerium) is. Christus self roep die diens-amp in die kerk na vore omdat Hy sy kerk wil regeer deur die diens van mense. Daarom is die ampsdraers primêr diensknegte van God deur wie se dienswerk God sy heil aan mense gee (Confessio Helvetica posterior, 1560, VXIII 3).

Hier is dit duidelik dat die amp nié 'n verbesondering van die algemene priesterskap van die gelowiges is nie, die amp kom nie as vanself uit die gemeente na vore nie, maar is 'n gawe van God aan die gemeente (Efesiërs 4:11-12). Die dienswerk wat deur Calvyn onderverdeel word in die dienswerk van die predikante, ouderlinge en diakens het ten doel die verkondiging, die orde in die gemeente en die bewaring van die Christelike lewenstyl en die onderhouding van die barmhartigheidsdiens, met ander woorde die opbou van die gemeente (Confessio Gallicana, 1559, 24 en Confessio Belgica, 1564, 30). In opdrag van Christus word hierdie dienswerk verrig en as sodanig is dit die middel waardeur Christus sèlf sy gemeente in stand hou.

Hierin is die gesag van die diens-amp geleë (vgl II Kor 5:20, 1 Kor 4:1, II Tim 3:17, 1 Tess 5:12, 17 asook Luk 10:16) wat egter nié 'n onafhanklike gesag is nie, maar absoluut aan Christus gebind is (Matt 28:18). In die kerk geld net één gesag, dit is die gesag van Christus sodat gesê kan word dat die regering van die kerk' $n$ duidelike Christokrasie is.

Omdat dit Christus is wat self sy kerk regeer, daarom is àl die ampsdraers van gelyke status. Die anti-hiërargiese inrigting van die amp kom dan ook in àl die calvinistiese kerkordes voor en vind sy verdere uitdrukking dáárin dat die ampsdraers nooit alleen optree nie, maar deur middel van die vergadering hulle dienswerk beplan (vgl AD Pont, s j, bl 104 v).

Een van die duidelikste, kort samevattings van die amp in die kerk kan gevind word by Confessio Genevensis 1536, art 20:

"Ons erken géén herders in die kerk nie as die getroue herders van die Woord van God wat die skape van Jesus Christus voed 
aan die een kant met onderrig, vermaning, vertroosting, aanmoediging en teregwysing en aan die ander kant deur weerstand te bied aan alle valse leringe en verleidings van die duiwel sonder om die suiwere leer van die Heilige Skrif met hulle eie drome of inbeeldinge te vermeng. Aan hierdie herders skryf ons geen ander mag of gesag toe as om die volk van God, wat deur die Woord aan hulle toevertroue is, te lei en te regeer nie. Deur die Woord het hulle die gesag om te beveel, te verde$\mathrm{dig}$, te beloof en te waarsku, maar daarsonder kan en behoort hulle niks te onderneem nie.

Aangesien ons die ware diensknegte van die Woord ontvang as boodskappers en gesante van God, is dit nodig om na hulle te luister soos na Christus sèlf en ons beskou hulle dienswerk as 'n opdrag van God wat vir die kerk nodig is.

Aan die ander kant hou ons daaraan vas dat alle verleiers en valse profete, wat die suiwere evangelie verwerp en afwyk na hulle eie opvattings, glad nie in die kerk verdra of gehandhaaf kan word nie. Hulle wat nie die herders is wat hulle voorgee om te wees nie, maar wel eerder rasende wolwe is, behoort verjaag en verwerp te word uit die geledere van die volk van God."

\section{SAMEVATTENDE OPMERKINGS}

Met die leer van die priesterskap van die gelowiges word primêr gebruik gemaak van Petrus se uitdrukking waarmee hy sowel die roeping en mondigheid van die gemeenskap van die gelowiges wil uitdruk as die onmiddellike verband tussen Christus die Hoëpriester en almal wat aan Hom behoort. Dit is duidelik dat as Luther die priesterskap van die gelowiges so beklemtoon hy dit doen in sy stryd téén Rome en die hiërargies-geordende priesterdom wat in daardie kerk die verkondiging van die Woord doodgesmoor het. Dit was in die jare 1520 en daarna die ideale argument om een van die pilare, waarom die pouslike kerk gebou was, om te ruk. Dat die begrip priesterskap van die gelowiges maar één van die uitdrukkingswyses is om die roeping, dienswerk en mondigheid van die gelowige uit te druk, staan vas. 'n Parallelle beeld is dié wat Paulus gebruik van die liggaam van Christus, ' $n$ beeld waaraan Calvyn die voorkeur gee. Op grond daarvan en in navolging van Kuyper, kan daar ook gepraat word van die amp of dienswerk van 
die gelowiges (H Bouwman, 1970, Dl 1, bl 330). As Kuyper die amp van die gelowiges beklemtoon, is dit ook in die polemiese situasie van die laaste dekades van die $19 \mathrm{de}$ eeu in Nederland. Dan, teenoor die organisatoriese struktuur van die Nederlandse Hervormde Kerk wat volgens die verenigingsreg gebou is, beklemtoon Kuyper met dié uitdrukking die mondigheid èn die noodsaaklikheid van die gelowige lidmaat se medeverantwoordelikheid vir die voortgang van die dienswerk van die kerk in die wêreld. Miskien is hierdie uitdrukking ook nie die beste nie omdat dit weer verwarring skep ten opsigte van die "besondere ampte" vir die kerk. Bo en behalwe hierdie uitdrukkings kan ook nog gepraat word van die nuwe verbond, die volk van God, die kerk. Met al die verskillende beelde word gesê dat Jesus Christus die enige Hoof en Heer van sy kerk, sy volk, sy uitverkorenes is en dat daar 'n innige gemeenskapsband, deur die geloof, tussen Christus en dié wat aan Hom behoort, bestaan.

Die priesters, die gelowiges, die volk van God, het 'n bepaalde roeping en opdrag om God te dien en Hom gehoorsaam te wees en andersyds om mekaar ook by te staan èn op te bou. Daarin word die gemeenskap van die gelowiges bygestaan en gelei deur die Woord van God èn God, die Heilige Gees.

Omdat die gemeente, die kerk, die volk van God in die wêreld leef en die gelowiges geregverdigde sondaars is, daarom roep God self sommige van die gelowiges tot die besondere diens of amp. Deur middel van diế dienswerk van die ampsdraers moet "die ware godsdiens onderhou word en die ware leer oral versprei word, die oortreders op geestelike wyse vermaan en in toom gehou ... word en, ... die armes en bedroefdes volgens hulle nood gehelp en getroos ... word."

Dit wil dus sê dat die amp-dienswerk ingestel is om die priesterskap van die gelowiges te aktiveer. Die ampsdraer self word tot sy dienswerk geroep en ontvang van Christus die bekwaamheid om sy dienswerk so te verrig dat dit tot heil van die kerk, die gemeenskap van die gelowiges sal wees.

So gesien is die amp-dienswerk èn die gemeente onlosmaaklik met mekaar verbind. Onder die hoofskap van Jesus Christus, gelei deur Woord en Gees, moet ampsdraer en gemeente, die amp en die koninklike priesterdom saamleef en saamwerk in die wêreld, tot die uitbou en opbou van kerk en koninkryk èn tot eer van God. 
CALVINUS, J 1559. Institutio christianae religionis.

KLUG, I 1939. Het Katholieke Geloof. Heemstede.

LIEBERG, H 1962. Amt und Ordination bei Luther und Melanchton. Gottingen.

NIESEL, W 1957. Die Theologie Calvins. München.

PONT, AD 1960. 'n Dogmenhistoriese Skets van die Leer van die Algemene Priesterskap van die Gelowiges, artikel in Hervormde Teologiese Studies, Krugersdorp Jrg 20.

PONT, AD 1981. Die Historiese Agtergronde van ons Kerklike Reg, Dl 1, Pretoria.

PONT, AD, Die Betekenis van die Meerdere Vergaderings ten opsigte van hulle gesag, funksie en handelinge in die kerk, atikel in Hervormde Teologiese Studies, Pretoria s j, Jrg 38.

STEIN, W 1974. Das Kirchliche Amt bei Luther. Wiesbaden.

VAN 'T SPIJKER, W 1970. De Ambten bij Martin Bucer. Kampen. 